\title{
CLIMATE RESILIENCE OF COLLECTIVE WATER MANAGEMENT IN RURAL JAPAN
}

\author{
Mami Shiono*, Koichi Ikegami, Tadasu Tsuruta
}

\author{
Department of Environmental Management, Graduate School of Agriculture, Kindai \\ University, 3327-204 Nakamachi, Nara, 631-8505, Japan \\ * Corresponding author: E-mail: 1644680004e@nara.kindai.ac.jp
}

Citation: Shiono, M. Ikegami, K., Tsuruta, T., 2017. Climate Resilience of Collective Water Management in Rural Japan . J. Asian Rur. Stud. 1(2): 162-171

\begin{abstract}
Building resilience of rural communities is crucial to minimize damages caused by external factors including climate change. This paper attempts to analyze climate resilience in farmer-based irrigation system in rural Japan. This paper focuses on the Kako area in Hyogo Preefecturre, where farmers had been confronted water shortage for a long time. The Kako Land Improvement Dstrict (LID) is reponsible for water control. This paper is based on the interview with Kako LID officials and the documents kept by the LID office. Examining emergency measures taken against a severe drought in a water users association in western Japan, this paper reveals that former communal values on water allocation still survive even in an apparently modernized and individualized irrigation scheme. When the group encountered an acute shortage of rain, former communal approach in controlling water was re-introduced without hindrance, displaying remarkable resilience of village-based organization in times of emergency and crisis.
\end{abstract}

Keywords: resilience; collective action; wet-rice irrigation; Japan

\section{Introduction}

Recently, there is a growing concern about the negative effects of climate change on agriculture and food security in the world. FAO, for example, is currently promoting climate resilient agriculture, regarding 2016 as a year of action for climate change. One of the goals of such a promotion is to build resilience of small farmers, who are thought to be most vulnerable to natural disaster, by increasing their capability to adapt themselves to changing climatic condition. By shifting from traditional ways of farming to "climate-smart" agriculture, farmers not only conserve soil and water, but can also increase agricultural productivity and income (FAO 2016).

In the context of agriculture and climate change, resilience may be defined as the ability of individual farmers or rural communities (or wider social systems) to maintain their patterns of farming and livelihood, or to recover from damages, in the face of disturbance. Most studies on climate change resilience in agriculture have so far focused on technological aspects such as crop diversification (Lin, 2011) and water saving irrigation (Zou et al., 2012). As the resilience of a given community may be determined primarily by its capability as a group to mitigate the external effects, it should be studied not only from technological viewpoint, but also from sociological viewpoint, in order to find a desirable social institution and a way of resource management in each rural community (RIHN, 2008). 
This paper, therefore, focuses on social aspects of climate change resilience in the case of collective water management system in rural Japan. Wet-rice irrigation in Japan has been managed by farmer-based water users associations organized along each water system, which are characterized by collective action of villagers and local knowledge and skills on water control (Sugiura et al. 2015). Such a long-standing communal institution may have been closely related to remarkable resilience of each village in the past, which was demonstrated in times of crisis. At the same time, whether or not such a communal approach to water management still works today in case of emergency remains to be studied.

This paper aims to examine climate change resilience of a water users' association, Kako Land Improvement District, which is located in Inami Town, Kako County, Hyogo Prefecture in Western Japan (Figure 1). Although Kako had long been a drought-prone area, development of modernized irrigation system has recently overcome a shortage of water in the area, leading to a more individualized on-farm water management. At the same time, rapidly aging village communities found it difficult to retain former participatory management of irrigation. Bearing this in mind, this paper attempts to analyze how villagers in Kako area responded to a severe drought in 2005.

\section{Methodology}

This paper is based on the first author's fieldwork in Kako area, which was carried out at irregular intervals between July and October 2014. The bulk of the information in this paper comes from formal and informal interviews with officials in Land Improvement Districts in Kako County. A Land Improvement District (LID) is a formal responsible organization for water control and maintenance of irrigation and drainage facilities. Usually, some officials of a LID are engaged in water engineering, thus, they know formal rules for water distribution as well as custums in a case of emmergency such as draught. And they keep variable documents related to water distribution. Accordingly, interviews with LID officials and collecting such documents are most important for understaning the nature of irrigation water use in rural Japan.

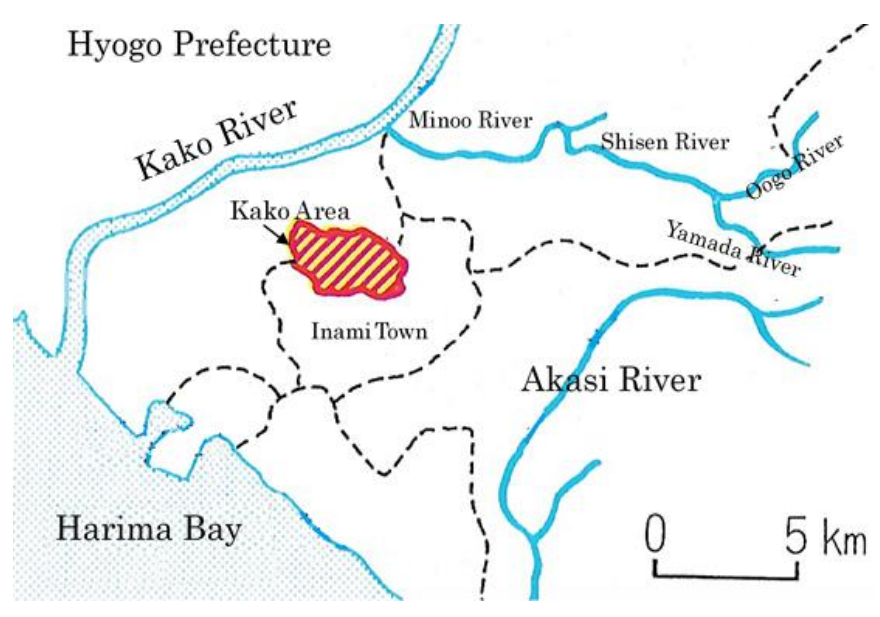

Figure 1. The Location of Kako Land Improvement District Source: Kako LID (1995). 
Kako LID was selected as a main subject of study among a number of LIDs in Kako County (See Figure 1), because it is situated in the water deficit area and keeps sufficient documents, in particular, those concerning water control when rainfall is not enough. Main items of interviews include its organizational structure, its relations with villages, system of water distribution, water control in 2005 when rainfall was insufficient, and farmers' response to this emergency control of water.

\section{Community-based Water Management in Wet-rice Cultivation in Japan}

Japanese paddy field irrigation system has long been characterized by communal approach to managing water resources (Hatcho and Matsuno, 2005). In such a communal system, priority was placed on equity among members over individual benefit. In many cases, the present irrigation schemes in Japan are founded on existing village communities, which were originally formed on the basis of local units of wateruse between late mediaeval and pre-modern Edo period (1603-1867). In early modern period, a united water users association would also be formed to cover a wider area, in the case of multiple villages depending on single irrigation scheme (Tamaki, 1982). In the Meiji period (1868-1912), water users' associations came to be regulated by modern laws to strengthen government's control on grassroots water-use. Though such legal associations were officially made up of landowners, the actual management on the ground was assumed by villagers as a continuation of pre-modern water users associations (Tamaki, 1984).

After the end of the World War Two, Land Improvement Act was enacted in 1949 to encourage implementation of large-scale irrigation schemes, and many informal water users associations were transformed into modernized legal bodies, i.e. Land Improvement Districts (LID). Although LID is a group of water users who manage new irrigation facilities installed under the above law, it is also a farmer-based water management organization, based on existing local communities. The subject of this study, Kako Land Improvement District, also has a long pre-history of its own before its establishment in 1952, to which we now turn our attention.

\section{Historical Outline of Wet-rice Irrigation in Research Area}

Kako Land Improvement District (LID) is located on a large tableland called Inamino Plateau, which lacks natural water resources due to its topographical condition. Average rainfall in this area is $1,200 \mathrm{~mm}$ per annum, as compared to national average of $1,700 \mathrm{~mm}$. There is no reliable water source such as big rivers in its neighborhood. Local residents had therefore built reservoirs to secure water for irrigation to grow wet rice. The origin of the irrigation scheme in Kako dates back to a pioneer village built in 1661 on the basis of newly reclaimed paddy fields. Himeji Han (feudal domain), or local government at that time, built Kako Oh-ike in 1669 to supply water to these fields. Kako Oh-ike is one of the largest surviving reservoirs in Hyogo Prefecture and still functions as the "mother pond" in irrigation scheme in Kako LID.

Water in Kako Oh-ike had been replenished from a long canal driving from Kusatani River, which is located at $4 \mathrm{~km}$ from the pond. As the right to take water from Kusatani River was granted only in non-irrigation season, the Kako area had always been suffering from water shortage. In the Meiji period, a new water source was secured by another canal from Ougo River, which was excavated between 1888 and 1891. The total 
length of the canal was $26.3 \mathrm{~km}$, supplying water to 1,112 ha of fields in total. After the construction, however, the area faced a water shortage again because of increased cultivation of wet rice replacing cotton, which had been planted to alleviate chronic water shortage. In times of drought, villagers had to cut back on planting acreage of wet-rice (buиe), an age-old custom which dates back to the Edo period, although several wells were installed to supplement irrigation water. The water shortage problem was finally resolved by the construction of a canal from Donto Dam on Yamada River, which is located at around $14 \mathrm{~km}$ from Kako area. This land improvement project (Toban Yosui Agricultural Irrigation Project, total beneficiary area of 8,040 ha) started in 1970 and then completed in 1992, providing supplementary water to Kako area. The water from Donto Dam is once saved in Kako Oh-ike reservoir, and is allocated to individual paddy fields along with water from five wells, passing through several small reservoirs as adjuster ponds. Thus, the process of modernizing irrigation (Ikegami 1991: 67-72) was finally completed in the early 1990s, and irrigation water is now available through valves and pipelines.



Photo 1. A Satellite Photo of Kako Area

Source: Retrieved from the official web site of Inami Town.

\section{Participatory Water Management in Kako LID}

\subsection{Current water allocation system}

Total beneficiary area of Kako LID in 2014 was 300 ha (wet paddy fields 298 ha and upland fields 2 ha). 12 villages were covered in this irrigation scheme and the total number of member farmers was 830 in 2014. The executive board was made up of 12 directors, 35 representatives, and three inspectors, all of whom were elected from each village by members. The members were made up of both farmers and non-farmers who possessed farmlands in LID area. The organization was managed by dues paid by members. Annual dues were divided into "recurrent dues" which covered everyday fees for facility maintenance and administration, and "special dues" which was saved up for a large scale repair or rehabilitation of irrigation facilities. The amount of annual recurrent dues per 10 ares was 3,000 yen for wet paddy fields and 1,500 yen for upland fields, while that of special dues are 2,500 yen for wet paddy fields and 1,500 yen for 
upland fields, respectively. Major irrigation facilities in the LID are ten reservoirs including Kako Oh-ike, the mother pond, and five drilled wells.

Currently, water is allocated through pipelines and valves from Kako Oh-ike among members' fields. Before the consolidation of paddy fields, water channels were spread over the area, and Kako Oh-ike had sluice gates and waterways each connected exclusively to respective village. Each village elected a water master who was in charge of taking water from the mother pond into a channel connected to his village. These twelve water masters were called oh-mizu ire ("big water takers"). Furthermore, one or a few villagers were in charge of water control within the domain of each village (mizuire or "water takers"). These "water takers" were specialists with skills of water control and management, and they had a voice in deciding, for example, whether or not to impose restriction on paddy cultivation (buue) in the case of drought. Formerly, because of chronic shortage of water, efforts to avoid wasting water had always been made. However, the construction of canals from Dondo Dam, coupled with farmland consolidation, made abundant water available through pipelines and valves. The position of water masters or "water takers" was abolished and each individual famer can now use water freely almost without restriction. Water is now managed by water management committee members who are selected from each village, closely coordinating with the LID office. According to the president of Kako LID, as a result of "modernization" of irrigation system, water control of each farmer is gradually becoming relaxed, and the amount of water consumption in the LID is increasing every year.

\subsection{Changes in Farming Households}

After water supply became stable with the construction of the canal from Donto Dam in 1992, the makeup of farming households in the villages had considerably changed. Table 1 reveals the changes of farm household composition in twelve villages between 1990 and 2010. As shown in the table, total number of farming household decreased considerably from 559 to 374 or $30 \%$ during this period. At the same time, the number of full-time farming household doubled, although the number itself is still relatively small. This may reflect a national policy which promotes concentration of farm management to a smaller number of large-scale farmers. Table 2 suggests that there is a tendency for farm size expansion in recent years.

According to a report from the MAFF (2012: 27), expansion of farm size may lead to a wasteful use of irrigation water, because it would be difficult to make a careful water control by one or a few large-scale farmers, in comparison to former collective management of irrigation water. Thus expansion of individual farm size may have contributed to the increase of water use in the LID area.

\subsection{An Analysis of the Amount of Water Consumption}

We now examine whether the amount of water consumption in Kako LID actually increased or not. Figure 2 shows the amount of water supplied from Donto Dam to Kako Oh-ike, along with rainfall between January and September of each year, a period during which water from the Dam was supplied. Supplied amount is calculated as an average per 10 ares rather than the total amount, because the farmland area in the LID 
has been decreasing every year, from 348 ha in 1952 (when Kako LID was established) to 300 ha as of 2014. This figure shows that there was little rain in the year 2005. In such a year of rainfall deficit, supply from Donto Dam increased. This is because many fields would dry up in the case of little rain and water from surrounding catchment area would also be scarce.

Table 1. Farming Household Composition in Kako Area (1990-2010)

\begin{tabular}{ccccccccccc}
\hline $\begin{array}{c}\text { Name } \\
\text { of } \\
\text { village }\end{array}$ & $\begin{array}{c}\text { Total Number } \\
\text { of Farming } \\
\text { Household }\end{array}$ & $\begin{array}{c}\text { Commercial } \\
\text { Farming } \\
\text { Household* }\end{array}$ & $\begin{array}{c}\text { Full-time } \\
\text { Farming } \\
\text { Household }\end{array}$ & $\begin{array}{c}\text { Part-time Farming } \\
\text { Household } \\
\text { (Type1)* }\end{array}$ & $\begin{array}{c}\text { Part-time Farming } \\
\text { Household } \\
\text { (Type2)* }\end{array}$ \\
\hline A & 60 & 48 & 38 & 27 & 1 & 3 & - & 1 & 37 & 23 \\
\hline B & 25 & 21 & 19 & 16 & 2 & 3 & 1 & - & 18 & 13 \\
\hline C & 66 & 52 & 50 & 35 & 3 & 5 & 5 & 1 & 42 & 29 \\
\hline D & 18 & 11 & 12 & 10 & - & 4 & - & - & 12 & 6 \\
\hline E & 59 & 28 & 37 & 19 & 3 & 4 & - & - & 34 & 15 \\
\hline F & 34 & 19 & 27 & 12 & 5 & 3 & - & - & 22 & 9 \\
\hline G & 65 & 33 & 51 & 20 & 3 & 5 & 1 & - & 47 & 16 \\
\hline H & 55 & 35 & 38 & 22 & 3 & 4 & - & 1 & 35 & 17 \\
\hline I & 28 & 27 & 22 & 18 & 1 & 6 & 2 & 1 & 19 & 11 \\
\hline J & 77 & 43 & 55 & 25 & - & 5 & 1 & 1 & 54 & 19 \\
\hline K & 19 & 19 & 12 & 12 & - & 2 & - & - & 12 & 12 \\
\hline L & 53 & 38 & 32 & 25 & 3 & 7 & 2 & - & 27 & 18 \\
\hline Total & $\mathbf{5 5 9}$ & $\mathbf{3 7 4}$ & $\mathbf{3 9 3}$ & $\mathbf{2 4 1}$ & $\mathbf{2 4}$ & $\mathbf{5 1}$ & $\mathbf{1 2}$ & $\mathbf{5}$ & $\mathbf{3 5 9}$ & $\mathbf{1 8 8}$ \\
\hline
\end{tabular}

Source: National Agricultual Census (2010).

Note*: In the terminology of agricultural statistics in Japan, "commercial farming household" means a household which either has more than 30 ares of area under cultivation, or earns more than 500,000 Japanese yen per year. Parttime farming households are divided into two types: type 1 denotes those who earn more from on-farm than from offfarm activities, while type 2 households earn more from off-farm than on-farm activities.

Table 2. Area under Cultivation of Farming Households in Kako Area

\begin{tabular}{ccc}
\hline Area under Cultivation & Number of Household (1990) & Number of Household (2010) \\
\hline Less than 0.5ha & 117 & 69 \\
\hline $0.5 \sim 1.0 \mathrm{ha}$ & 218 & 126 \\
\hline $1.0 \sim 2.0 \mathrm{ha}$ & 56 & 38 \\
\hline $2.0 \sim 3.0 \mathrm{ha}$ & 2 & 3 \\
\hline $3.0 \sim 5.0 \mathrm{ha}$ & - & 4 \\
\hline $5 \sim 10 \mathrm{ha}$ & - & 4 \\
\hline $10 \sim 20 \mathrm{ha}$ & - & 3 \\
\hline More than 20ha & - & -
\end{tabular}

Source: National Agricultual Census (2010). 


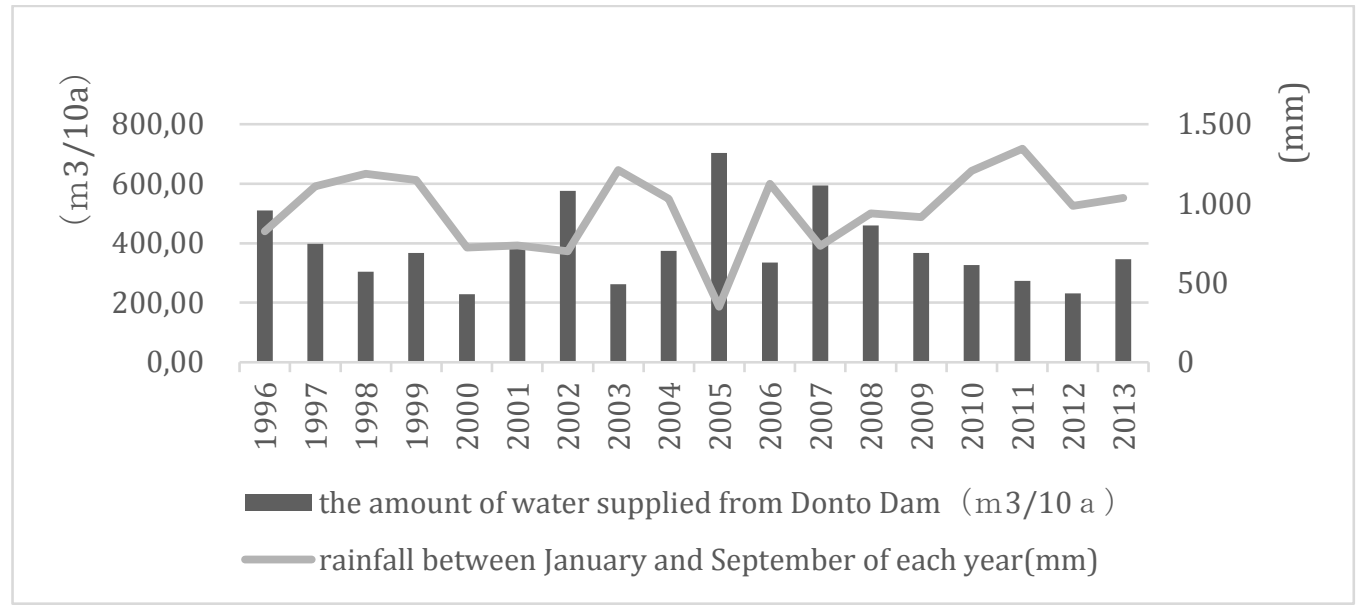

Figure 2. Water Supply to Kako Oh-ike and Rainfall

Sources: Data from Toban Yosui LID in charge of Donto Dam and Amedas Miki City.

Figure 3 shows the trend in the total water supply, calculated as an aggregate of both amount supplied from Donto Dam and rainfall (Jan.- Sept.). Note that water pumped up from wells is not included here, because the accurate data was not available. Although the actual amount goes up and down depending on each year's climate, the linearized approximate curve shows a gradual upward tendency, providing evidence for aforementioned statement by the LID president, saying that the water consumption in LID was increasing.

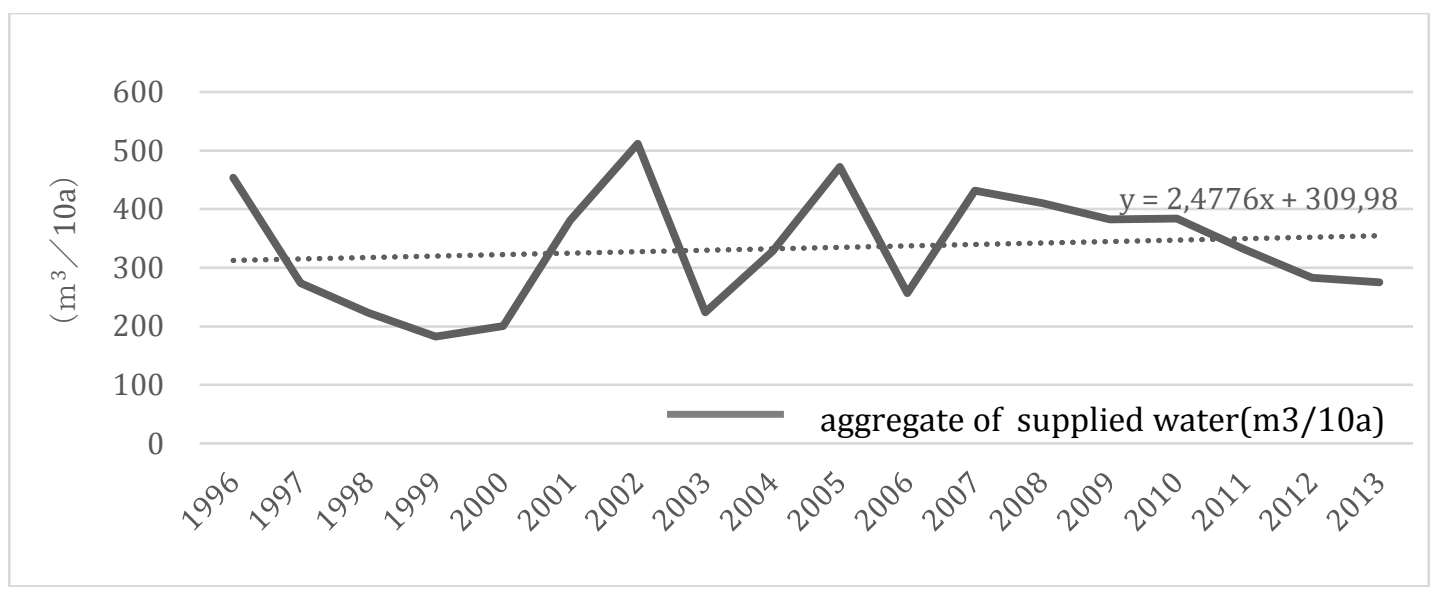

Figure 3. Total Supply of Irrigation Water in Kako LID (Supply from Donto Dam plus Rainfall) Source: Data from Toban Yosui LID in charge of Donto Dam and Amedas Miki City.

\section{Collective Action in the Face of Drought}

The tendency towards individualized water use seems to have been reversed when a serious drought struck Kako LID in 2005. According to data on rainfall in Miki Observatory, the nearest observatory to Kako area, an average annual precipitation between 1981 and 2010 was 1,165 mm. Rainfall in 2005 was at unusually low level of $687 \mathrm{~mm}$, or $60 \%$ of the average, ranked second to the lowest record of 1994. In 2005 
cropping season, there was little rain during the spring. The LID office then called out to member-farmers for saving irrigation water, by using cable broadcasting. Facing the acute shortage of rain, emergency meeting of board members was held on the 1st July, and they decided to take several emergency measures, after examining various data including precipitation from May, the water level of Kako Oh-ike, and the water storage rate of Donto Dam, which was as low as $48 \%$. The starting date of water saving measures was settled to be the 20th July, which coincided with the start of midsummer drainage or nakaboshi.

Table 3 shows the chronology of emergency actions taken against drought from the 17th July to the 20th September in 2005. This is based on a detailed record kept by the LID office, which includes various issues, ranging from water levels of reservoirs including Donto Dam, to consultations made with related authorities. This table demonstrates clearly LID office's firm resolution not to create even single sacrifice field. According to the record, the sluice gates of the mother pond were often closed to save water, and the whole area was closely patrolled when the gates were open. Patrols were organized mainly to check the condition of fields without water, rather than to keep surveillance over invalid water-release. Furthermore, water in the drainages was pumped up even late at night in order to supply water to the waterless fields.

After mid-summer drainage period, which normally lasts around ten days, enough water has to be secured for rice plants which are then coming into ears. As the members could not expect water allocation from Donto Dam, they frequently closed the sluice gates of the mother pond, Kako Oh-Ike, and instead pumped up water from smaller reservoirs and drains downstream, and allocated it to individual plots. C Village had some fields without sufficient water due to their proximity to Kako Oh-ike. C Village was then given priority to get pumped-up water on the 8th August, around one week after the end of mid-summer drainage (Table 3).

Table 3. Chronology of Emergency Measures against Drought in 2005

\begin{tabular}{|c|c|c|c|}
\hline Date & $\begin{array}{l}\text { The sluice } \\
\text { gates of } \\
\text { Kako Oh-ike }\end{array}$ & Board members & Activities \\
\hline 17th July & \multirow[t]{4}{*}{ open } & Emergency meeting & $\begin{array}{l}\text { Setting up patrols to monitor water levels within the LID area, } \\
\text { and making a timetable for water saving measures }\end{array}$ \\
\hline 18th & & \multicolumn{2}{|c|}{ Starting patrols and delivering the timetable to each village } \\
\hline 19th & & \multicolumn{2}{|c|}{ Arranging the date of cable broadcasting to call out to villagers for cooperation } \\
\hline 30th & & \multicolumn{2}{|c|}{ Distribution of emergency newsletter no. 1 to members } \\
\hline 2nd August & \multirow[t]{2}{*}{ closed } & Emergency meeting & Field survey on reservoirs \\
\hline $3^{\text {rd }}$ & & \multicolumn{2}{|c|}{ Cutting grasses in waterways connected to reservoirs to make water flow smoothly } \\
\hline $6^{\text {th }}$ & \multirow[t]{2}{*}{ open } & Emergency meeting & Exchange of information on water supply in each village \\
\hline $7^{\text {th }}$ & & Emergency meeting & $\begin{array}{l}\text { Discussing measures to supply water to waterless fields } \\
\text { Pumping up drained water to provide it to waterless fields until } \\
\text { late at night } \\
\text { Confirming that water level in C Village was decreasing }\end{array}$ \\
\hline $8^{\text {th }}$ & \multirow[t]{3}{*}{ closed } & & Supplying pumped-up water to C Village \\
\hline 10th & & Emergency meeting & $\begin{array}{l}\text { Preparing pumps to draw water from reservoirs in the LID } \\
\text { Discussing how and when water should be allocated across the } \\
\text { area }\end{array}$ \\
\hline 12th & & Emergency meeting & Pumping up water in the reservoirs \\
\hline 13th & open & Emergency meeting & $\begin{array}{l}\text { Patrols } \\
\text { Checking the acreage fed by pumped-up water } \\
\text { Checking areas without water and discussing how to allocate } \\
\text { water to these areas. Allocating water until late at night }\end{array}$ \\
\hline
\end{tabular}




\begin{tabular}{|c|c|c|c|}
\hline 14th & \multirow[t]{3}{*}{ closed } & Emergency meeting & $\begin{array}{l}\text { Exchange of information on allocation of water } \\
\text { Closing the sluice gates }\end{array}$ \\
\hline 22nd & & Emergency meeting & Deciding to open the sluice gates on the 25 th \\
\hline $23 \mathrm{rd}$ & & \multicolumn{2}{|c|}{ Distribution of emergency newsletter no. 3 to members } \\
\hline 25 th & $\begin{array}{l}\text { open and } \\
\text { closed }\end{array}$ & & Repeating open and closing of the sluice gates until the 27 th \\
\hline 28th & \multirow[t]{3}{*}{ closed } & & \\
\hline $31 \mathrm{st}$ & & Emergency meeting & Deciding to open the sluice gates on the 3 rd \\
\hline 1st September & & \multicolumn{2}{|c|}{ Distribution of emergency newsletter no. 4 to members } \\
\hline $3^{\text {rd }}$ & $\begin{array}{l}\text { open and } \\
\text { closed }\end{array}$ & & \\
\hline $6^{\text {th }}$ & \multirow[t]{3}{*}{ closed } & & \\
\hline 9th & & Emergency meeting & Deciding to open the sluice gates on the 13th \\
\hline 10th & & \multicolumn{2}{|c|}{ Distribution of emergency newsletter no.5 to members } \\
\hline \multirow[t]{2}{*}{ 13th } & \multirow[t]{2}{*}{$\begin{array}{l}\text { open and } \\
\text { closed }\end{array}$} & & $\begin{array}{l}\text { Repeating open (in the daytime) and closing (at night) of the } \\
\text { sluice gates until the } 5 \text { th }\end{array}$ \\
\hline & & & \multirow{2}{*}{$\begin{array}{l}\text { Stopping pumping up from wells. } \\
\text { Stopping pumping up from reservoirs and drainages by the 19th. }\end{array}$} \\
\hline 16th & \multirow[t]{2}{*}{ closed } & & \\
\hline 17 th & & \multicolumn{2}{|c|}{ Distribution of emergency newsletter no.6 to members } \\
\hline 20th & open & $\begin{array}{l}\text { Emergency measures } \\
\text { ended }\end{array}$ & \\
\hline
\end{tabular}

Source: Kako LID.

Table 4. Average Production of Rice in Inami Town, Hyogo Prefecture

\begin{tabular}{cc}
\hline $\begin{array}{c}\text { Period } \\
\text { (Year) }\end{array}$ & $\begin{array}{c}\text { Production } \\
\text { (husked rice, } \mathrm{kg} / 10 \mathrm{a})\end{array}$ \\
\hline $1995-2004$ & 508 \\
2005 & 533 \\
\hline
\end{tabular}

Source: Annual Statistics of Rice Production, Ministry of Agriculture, Forestry and Fisheries.

\section{Conclusion}

This paper has examined how Kako LID members weathered an unusual shortage of rain in 2005, by achieving a strong unity against crisis. Kako LID is located in a drought-prone region, and has formerly characterized by strict water control and restriction including buиe, or self-enforced reduction of plots under cultivation, which was traditionally carried out under a dry spell.

Today, an LID is a legal entity with a modernized irrigation system, and on-farm water use has gradually been individualized. At the same time, as it is still a selfgoverning water management institution of villagers, communal values and rules still persist, and a collective approach would be re-introduced in times of emergency and crisis. As we have seen, when a severe drought hit Kako LID, the leaders imposed a stricter water control, in contrast to a more relaxed water-use in normal times. Members, however, were very cooperative in accepting the emergency measures. As a result, they achieved a yield even higher than normal years.

Such a swift recovery from crisis shows remarkable resilience of collective irrigation system in Japan. This might be a unique case peculiar to rural Japan and may not be duplicated in other rice-growing societies, as Japanese villages have been characterized by a high degree of integration of members into a particular community, along with a rich inherited customs and skills on communal water management. At the same time, this case study suggests that, even in a highly modernized irrigation scheme as that of Kako LID, a crisis can be resolved not only by technological measures (such as pumping and controlling sluice gates) but also by sociological potential of a community 
to cope with unanticipated events, which is usually hidden and invisible. This also has important implications for the resilience of rice-growing communities in other Asian countries, where short-term technological development have tended to be given priority over encouraging grassroots initiatives.

\section{References}

FAO. (2016). The State of Food and Agriculture 2016: Climate Change, Agriculture, and Food Security. Rome: FAO.

Hatcho, N. and Matsuno, Y. (2005). The Participatory Approach of Managing Water in Japan. In (Coopy, R. et al. eds.) A History of Water Issues. Tokyo: United Nations University.

Ikegami, K. (1991). Water and Agriculture in Japan. Tokyo: Gakuyo-shobo (in Japanese).

Kako LID (Land Improvement District). (1995). A History of Kako Land Improvement District. Kako LID (in Japanese).

Lin, B. B. (2011). Resilience in Agriculture through Crop Diversification: Adaptive Management for Environmental Change. BioScience 61(3): 183-193.

MAFF (Ministry of Agriculture, Forestry and Fisheries). (2012). On Irrigation: A Report of Advisory Council on Food, Agriculture, and Rural Communities. Bureau of Rural Development, MAFF (in Japanese).

RIHN (Research Institute for Humanity and Nature). (2008). Vulnerability and Resilience of Social-Ecological Systems: FY2007 FR1 Project Report. Kyoto: RIHN.

Sugiura, M., Sato, Y. and Ota, S. (2015). The Framework of Skill and Knowledge Shared in Long-enduring Organizations in the Improvement of Irrigation Efficiency in Japan. In (Willems, W. J. H. and van Schaik, H. P. J.) Water \& Heritage: Material, Conceptual and Spiritual Connections. Leiden: Sidestone Press.

Tamaki, A. (1982). Social System in Japan. Tokyo: Nousan gyoson bunka kyokai (in Japanese).

Tamaki, A., Hatate, I., and Imamura, N. (1984). Social Structure of Water Use. Tokyo: United Nations University (in Japanese).

Zou, X. et al. (2012). How Water Saving Irrigation Contributes to Climate Change Resilience - a Case Study of Practices in China. Mitigation and Adaptation Strategies for Global Change17(2): 111-132. 